\title{
Possible effects of the Agaricus brasiliensis extract on the cardiac morphology in mice
}

\author{
LESSNA, E. ${ }^{1}$, BRUNING, L. F. ${ }^{1}$, BOLINA, C. S. ${ }^{2}$, LIMA, D. S. ${ }^{1}$, \\ WATANABE, $\mathrm{I} .^{3 *}$ and CIENA, A. P. ${ }^{3}$
}

\begin{abstract}
${ }^{1}$ Universidade Paranaense - UNIPAR, Rui Barbosa, 611, CEP 85801-470, Cascavel, PR, Brazil
${ }^{2}$ Departamento de Cirurgia, Faculdade de Medicina Veterinária e Zootecnia - FMVZ, Universidade de São Paulo USP, Av. Prof. Dr. Orlando Marques de Paiva, 87, CEP 05508-270, Cidade Universitária, São Paulo, SP, Brazil

${ }^{3}$ Departamento de Anatomia, Instituto de Ciências Biomédicas, Universidade de São Paulo - USP, Av. Prof. Lineu Prestes, 2415, CEP 05508-900, Cidade Universitária, São Paulo, SP, Brazil

*E-mail: watanabe@icb.usp.br
\end{abstract}

\begin{abstract}
Introduction: Mushroom extracts are used, mainly due to immunomodulatory and antitumor proprierties. Among the general and species is the Agaricus brasiliensis or SunMushroom. However herbal remedies can cause changes in morphology and functionality of various organs. Therefore, these reporters need to be analyzed for applicability of this compound. The aim of the present study was to analyze the structural characteristics of the heart of Swiss mice employing light microscopy and scanning electron microscopy methods. Materials and methods: Swiss mice were used, divided into 2 groups: Control ( $\mathrm{n}=6)$ and Agaricus brasiliensis ( $\mathrm{n}=6$ ), and the second group treated with the extract daily. After 60 days, under anesthesia withdrew from the samples, which were submitted to histological routine for obtaining serial sections. Results: Microscopic analysis revealed the aspects of the heart of Swiss mice: The formation of layers (epicardium, myocardium and endocardium) with partial view of the papillary muscles. Using the technique of Picro-Sirius: In yellow, the muscle fibers; in red, collagen fibers. Under polarized light, show the types of collagen fibers in red and green, significant collagen type I and III respectively. Conclusion: The arrangement of muscle fibers and collagen did not vary between the two groups.
\end{abstract}

Keywords: Agaricus, collagen fibers, heart, light microscopy, electron microscopy.

\section{Introduction}

Mankind has always turned to nature for food, shelter, transportation, fertilizer, flavoring and also products with medicinal activity. The first reports on the use of plants with therapeutic utilities are from Mesopotamia and date from about 2600 BC. (CRAGG and NEWMAN, 2005).

Mushrooms are widely known for their medicinal properties and appreciated in the culinary world. For centuries they have been used as food and therapeutic agents for having high nutritional value, high protein and fiber as well as small amounts of lipids. Therefore they are considered appropriate in a balanced diet (HENRIQUES, SIMEONE and AMAZONAS, 2008; KOMURA, CARBONERO, GRACHER et al., 2010).

Mushroom extracts are used mainly due to its immunomodulatory and antitumor properties (MOURÃO, LINDE, MESSA et al., 2009). Agaricus brasilisensis (A. brasiliensis), also known as $A$. blazei or sun mushroom is among the various genera and species tested. (COLAUTO, DIAS, GIMENES et al., 2002). The extract of $A$. brasiliensis, a mushroom of the subtropical regions of Brazil, has traditionally been used by health professionals as a food source in Brazil and for the prevention of diseases such as cancer, diabetes, hyperlipidemia, atherosclerosis and some chronic diseases, such as hepatitis (SINGI, DAMASCENO, ANDRÉA et al., 2006).
In eastern medicine, the use of $A$. brasiliensis was passed through generations and, more recently, in folk medicine in Brazil. They are pharmacologically active in the treatment of diseases due to its polysaccharides containing such as betaglicanas. They achieve good results in the treatment and prevention of various diseases. Furthermore, these mushrooms are evaluated as biological response modifiers, especially for its anti-tumor action (HENRIQUES, SIMEONE and AMAZONAS, 2008; LINDEQUIST, RAUSCH, FÜSSEL et al., 2010).

Herbal medicine toxicity as well as its possible side effects can often get overlooked in experimental studies. It is therefore a serious public health problem, since herbs can trigger adverse reactions due to their constituents and through interactions with medicines or food. In addition, factors such as age, gender, physiological condition, genetic characteristics, among others, may be related to these reactions. Furthermore, the usage without prescription, incorrect identification of plant species and their indiscriminate use can be harmful, lead to overdose, therapeutic inefficacy and / or adverse reactions (BALBINO and DIAS, 2010).

The aim of the present study was to examine the possible effects of chronic use of the $A$. brasiliensis extract in the morphological structural characteristics of female Swiss mice's heart to elucidate possible changes. 


\section{Material and Methods}

\subsection{Animals}

Twelve female Swiss mice, ageing 21 days old and weighing $25 \mathrm{~g} \pm 5 \mathrm{~g}$, were used from the animals' house of the Paranaense University- UNIPAR, Cascavel-PR and were kept in containment cages of polypropylene, with water and food "ad libitum" and light / dark periods of 12 hours at a temperature of $23{ }^{\circ} \mathrm{C} \pm 2{ }^{\circ} \mathrm{C}$. All procedures used in this study followed the ethical principles of animal experimentation adopted by the Brazilian College Experiment, being previously submitted and approved by the Ethics Committee on Animal Experimentation of the Paranaense University - Unipar / No. 18703.

\subsection{Experimental groups}

The 12 female Swiss mice were randomly divided into 2 groups:

- Simulacrum Group $(S):(n=6)$, given only water (vehicle);

- A. brasiliensis Group ( $\mathrm{Ab})(\mathrm{n}=6)$ administered the extract of A. brasiliensis.

\subsection{Preparation and administration of $A$. brasiliensis}

Samples of A. brasiliensis (A. brasiliensis 97/11) obtained from the Laboratory of Molecular Biology - UNIPAR were used. Next, they were dehydrated in a histology oven thermostated to $65{ }^{\circ} \mathrm{C}$. A solution was prepared containing mushrooms and water in the ratio of $1: 10$ and then heated at $90{ }^{\circ} \mathrm{C}$ for 12 hours. Subsequently, the solution was drained on filter paper of $80 \mathrm{~g} / \mathrm{m}^{2}$ (thickness of $205 \mu \mathrm{m}$ and a pore size of $14 \mu \mathrm{m}$.) The filtered solution was stored in a refrigerator at $4{ }^{\circ} \mathrm{C}$ for daily use and conservation throughout the experimental period. The administration of the solution containing the extract of A. brasiliensis was maintained at room temperature for five minutes before administration of the daily oral dose of $1 \mathrm{ml}$ for 60 days in the animals of Ab Group. The animals in S Group received in identical proportions and period as $\mathrm{Ab}$ Group, the aqueous solution (vehicle). The administration was performed in a separate room via gavage process. The materials used were insulin syringes $(1 \mathrm{ml})$ and gavage needles, both for water and A. brasiliensis extract administration.

\subsection{Light microscopy}

The animals in both groups $(n=4)$ were anesthetized with intraperitoneal ketamine $(50 \mathrm{mg} / \mathrm{kg}$ ) and xylazine $(10 \mathrm{mg} / \mathrm{kg})$. An anterolateral incision was made on the chest, elevating the rib cage and exposing the heart for dissection. Held collection, the samples were fixed in $10 \%$ formalin for 7 days and subsequently stored in $70 \%$ alcohol . Later, the organs were dehydrated in ascending series of alcohols, from $70 \%$ to absolute. After the diaphanization process the samples were embedded in histological paraffin. As soon as the blocks were obtained a serial cross sections of $6 \mu \mathrm{m}$ thick (Microtome Leica ${ }^{\circledR}$ - RM 2145) was performed and they were submitted to staining with Azo-carmine (AC), Hematoxylin and Eosin (HE) and Picrossirius (PS) (JUNQUEIRA, BIGNOLAS and BRENTANI, 1979). Image acquisition was performed using an optical microscope (Carl ZeissMicroimaging, Axiokop2, Göttingen, Germany) and a stereomicroscope (Carl Zeiss Microimaging, model Stemi SV6 ${ }^{\circledR}$ ), coupled with a digital camera (Power Shot A640, Canon, China). Image processing was performed in a computerized image (Axiovision Rel 4.0, Göttingen, Germany).

\subsection{Scanning electron microscopy}

The animals in both groups $(\mathrm{n}=2)$ were anesthetized with ketamine $(50 \mathrm{mg} / \mathrm{kg})$ and xylazine $(10 \mathrm{mg} / \mathrm{kg})$ via intraperitoneally, and their hearts were dissected. Then, they were immersed in modified Karnovsky solution containing $2.5 \%$ glutaraldehyde and paraformaldehyde $2 \%$ solution in sodium phosphate buffer $0.1 \mathrm{M}, \mathrm{pH} 7.4$ for 5 days at 4 ${ }^{\circ} \mathrm{C}$ according to the method reported by Watanabe (1998) and Duro, Ciena, Almeida et al. (2012). The samples were processed with the cryofracture technique by freezing in liquid nitrogen and postfixed in $1 \%$ osmium tetroxide for 2 hours. The samples were washed in distilled water, dehydrated in series of alcohol (70\% to absolute) and dried in a critical point apparatus (Balzers CPD- 30), using liquid $\mathrm{CO}^{2}$ (BOLINA, BOLINA-MATOS, ALVES et al., 2013). The samples were mounted on appropriate metal stubs, covered with gold ions in unit (Balzers SCD - 040) and examined in a scanning electron microscope, TM 3000 - Hitachi - Paulista State University/ UNESP, Rio Claro-SP.

\section{Results}

\subsection{Simulacrum group}

With the aid of a magnifying glass, mesoscopic analysis, in the evaluation of the histological heart, organization and composition of layers, as well as the two lower chambers: right and left ventricles, bounded by the interventricular septum were observed (Figure la).

Analyzing the layers, we observe: the epicardium placed more externally, which presented a serous constitutions with dense connective tissue; the myocardium or middle layer, composed by the arrangement of muscle bundles with greater thickening and endocardium, innermost layer made by simple squamous epithelium, forming internally a continuous blade with the endothelium. In the cardiac structure was possible to visualize the two lower chambers, the right and left ventricles, with partial view of the papillary muscles. It was observed by staining of AC, the left ventricle is thicker than the right. The muscle fibers were presented oriented in the longitudinal and transverse direction relative to the organ (Figure la).

The higher magnification in the gate region between the right and left ventricles was possible demonstrated, by $\mathrm{HE}$ staining, the interventricular septum formed by several layers of muscle fibers (Figure 1b).

Through of the stained by PS was possible to note, the muscle fibers and the highlighted collagen fibers revealed in red (Figure lc). Under polarized light the collagen fibers that form the epicardium appear in red, formed with predominantly type I collagen fibers (Figure $1 \mathrm{~d}$ ).

In Figures le and If the three-dimensional aspect of the ventricular's disposition and its constitution were observed by the cryofracture technique; highlighted for layers: endocardium, myocardium and epicardium.

\subsection{A.brasiliensis group}

With the aid of a magnifying glass, mesoscopic analysis, it was possible to observe the right ventricle (small) and left (large) with visualization of the papillary muscles, defined as conical muscular projections that are projections of muscular trabeculae of the inner walls of cardiac ventricles (Figure 2a). 

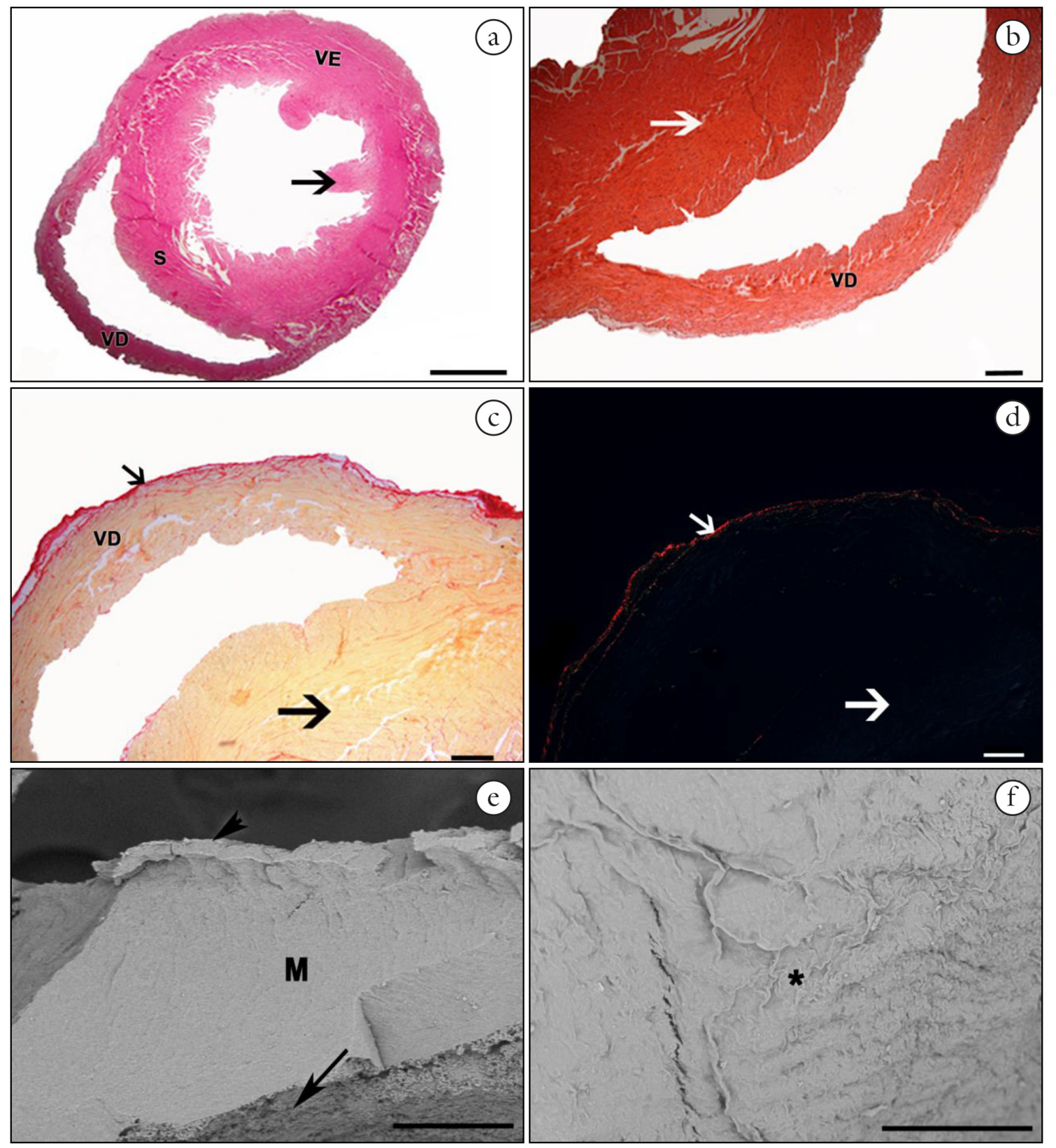

Figure 1. Light and electron micrographs Scanning Simulacrum Group: (a). Note the right ventricle (RV), left ventricle (LV) and interventricular septum $(S)$, with visualization of the papillary muscles (arrows). Coloration: AC. (b) In the largest increase, notice the ventricle (RV) and interventricular septum (arrow). Colour: HE. (c) It is observed the arrangement of muscle fibers in the interventricular septum (large arrow) and right ventricle (RV). In intense red the epicardium (smaller arrow). (d) Under polarized light, there is a predominance of type I collagen fibers in the epicardium (arrow) unlike the interventricular septum (large arrow). Coloration: PS. (e) reveals the layers of the heart: Epicardium (arrowhead), myocardium $(\mathrm{M})$ and the endocardium (arrow). (f) demonstrates the outer surface of the heart (*). Bars: (a) $1 \mathrm{~cm}$; (b, c and d) $200 \mu \mathrm{m}$, (e and f) $150 \mu \mathrm{m}$.

In high magnification, with HE staining, it was possible to visualize the right ventricle and interventricular septum, demonstrating the myocardium, the cell nuclei of cardiomyocytes (Figure 2b).

\section{Discussion}

The results of this study described the morphological and structural characteristics and the three-dimensional aspects of mice's hearts following administration by chronic period of the extract of $A$. brasiliensis.
The alternative and complementary medicine has been widely used by the population in recent years, especially in individuals in whom conventional therapy alone has shown no benefits. In 1997, a survey conducted in the United States with 2,055 people, $42 \%$ of them reported using some type of alternative medicine and / or complementary in the year prior to the study, including herbal medicines (BRAZ, PAULA, DINIZ et al., 2011).

Currently, studies have reported that the functions of the immune system can be modulated by beta-glucans 

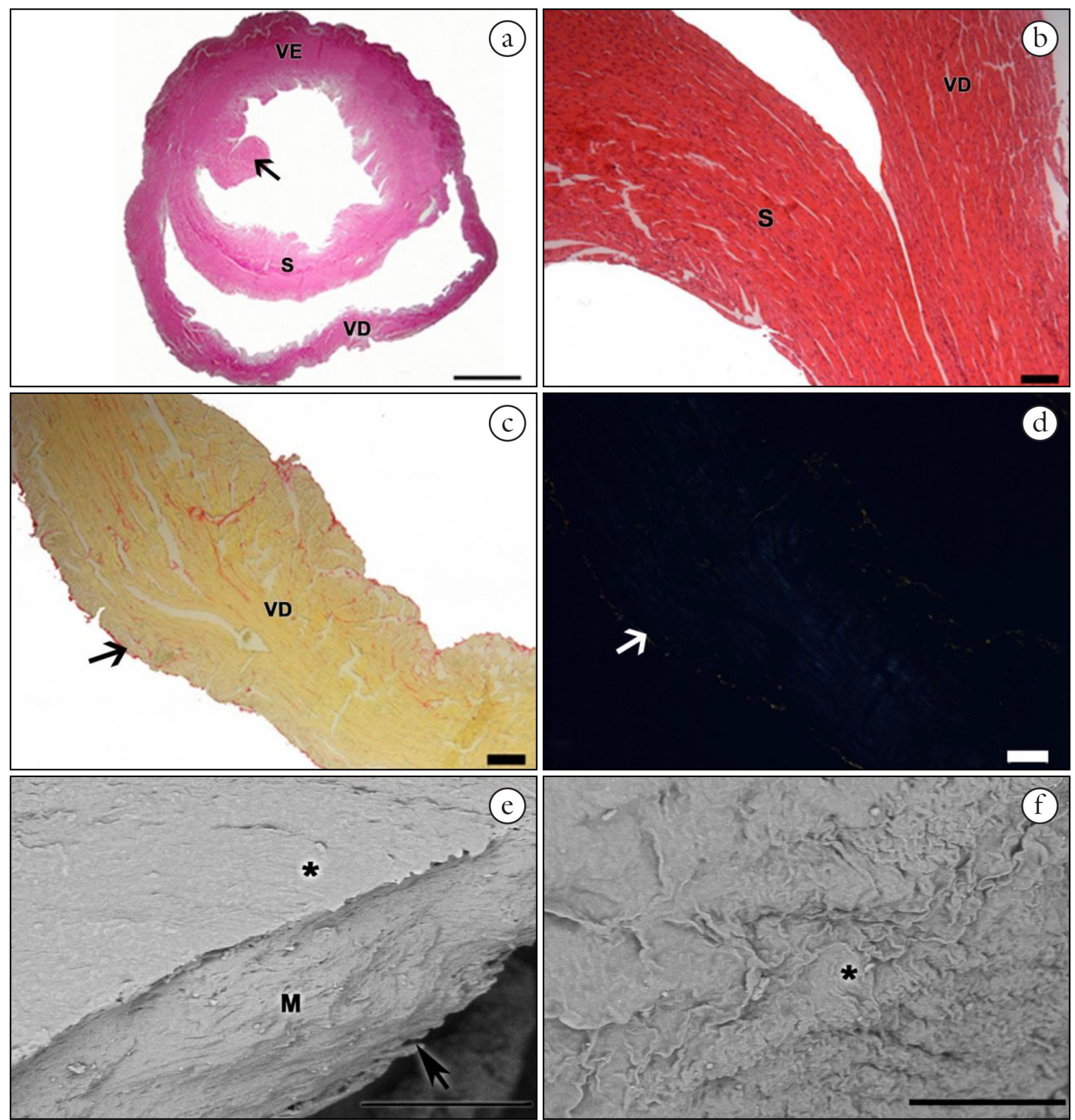

Figure 2. Light and electron micrographs Scan Group A. brasiliensis: (a) Arrangement of the right ventricle (RV), left ventricle (LV), interventricular septum $(S)$ and papillary muscle (arrow). AC staining. (b) In higher-grade increase if the interventricular septum (S) and the right ventricle (RV) showing the multinucleated cardiac fibers. Coloration: HE. (c) is observed in the right ventricle (RV), your muscle fibers, colored in yellow, interspersed with collagen fibers in the myocardium, also present in the endocardium and epicardium (arrow). Coloration: PS. (d) Under polarized light, note the predominance of type III collagen fibers (arrow). Coloration: PS. (e): Note the layers of the heart: Epicardium (*), myocardium (M) and the endocardium (arrow). (f) demonstrates the external surface of the heart $\left(^{*}\right)$. Bars: (a) $1 \mathrm{~cm} ;(\mathrm{b}, \mathrm{c}$ and d) $200 \mu \mathrm{m}$, (e and f) $100 \mu \mathrm{m}$.

polysaccharides present in the fruiting body or mycelia of a wide variety of edible mushrooms. Parallel to these reports, other studies describe that $A$. brasiliensis is particularly rich in polysaccharides and their use has demonstrated promising results of anti-inflammatory activity and anti nociceptive. In addition to these, they may have significant amounts of minerals such as calcium, zinc, iron, magnesium and phosphorus. The extracts are pharmacologically active in the treatment of diseases such as diabetes mellitus, atherosclerosis, hyperlipidemia, chronic hepatitis, gastric ulcers, osteoporosis, infections and various cancers (KOMURA, CARBONERO, GRACHER et al., 2010; NAGATA, HIGASHIUESATO, MAEDA et al., 2001; OLIVEIRA, ELER, BRACHT et al., 2010; PINTO, MARTINS, ROMAGNOLI et al., 2009; SMIDERLE, OLSEN, CARBONERO et al., 2008; SMIDERLE, RUTHES, VAN ARKEL et al., 2011). 
Experimental research on herbal medicines has demonstrated adverse effects, such as Camellia sinensis, that has been associated with hypertension and cardiac arrhythmia. There was also a reported case of drug-induced hepatitis. Atropa belladonna and Aesculus hippocastanum are also related to tachycardia and hyperthermia due to decreased sweating. There are reports of syndrome of pseudolupus with arthralgias, recurrent fever, myalgias, skin blemishes and cardiorespiratory changes due to use natural product called Venocuran (fenopirazona with A. hippocastanume miroton) (BALBINO and DIAS, 2010).

According to Balbino and Dias (2010), medicinal plants as Fucus vesiculosus can cause hyperthyroidism, tachycardia and hypertension, especially when associated with Equisetum arvense, Rhamnus purshiana, Passiflora sp. and Alexandrian Senna. Regarding Baubinia forficata; there were reported serious adverse reactions, such as liver problems, including cirrhosis and lower lumbar back pain (kidney pain).

In the study of Carraschi, Zaupa, Tsuzuki et al. (2003) it was evaluated the preclinical toxicity of the herbal Biotoss ${ }^{\circledR}$ in rodents (mice and rats), and reported a progressive decrease in the weight of kidneys of mice, reaching significant value in the group treated with a dose of $1.5 \mathrm{~g} / \mathrm{kg}$ via intraperitoneally. All groups treated orally reported points of bleeding in the kidney.

In another study with the plant Anemopaegma mirandum (catuaba) it was recorded the possibility of causing tachycardia in patients with Wolf-Parkinson-Wite, increased eye pressure and worsening of glaucoma, and contraindicated in pregnancy and in newborn babies. Side effects were also reported from the use of Passiflora genus plant, such as nausea, vomiting, dizziness, ECG changes, tachycardia, cataplexy, depression, hepatobiliary and pancreatic toxicity and hyperthyroidism. The same study found that the plant Cola nitida (cola nut) induces toxic effects as hyperexcitability, insomnia, gastric and duodenal ulcers, worsening hypertension and tachycardia (MELLO, LANGELOH and MELLO, 2007; MELLO, MELLO and LANGELOH, 2010).

According to Mukai, Watanabe, Ando et al. (2006), studying the case of a patient with ovarian câncer it was found that she showed hepatotoxicity in post surgical chemotherapy when combined with use of the herbal extract (A. brasiliensis). The chemotherapics were removed without any improvement. After the suspension of the extract of $A$. brasiliensis as medical advice, liver function returned to normal. In another case, described by the same author, breast cancer patient began treatment with extract of $A$. brasiliensis. During his hospitalization, liver damage was reported and level of his consciousness gradually deteriorated. Subsequently, the patient died with severe liver damage.

Some researchers suggest that these activities can occur due to an inhibition of inflammatory cells such as lymphocytes and macrophages, in addition to the decrease in the concentration of proinflammatory cytokines, such as interleukins, IFN- $\gamma$ and TNF- $\alpha$ (POUCHERET, FONS and RAPYOR, 2006).

According to Nakajima, Ishida, Koga et al. (2002), demonstration $A$. brasiliensis induced increase in production of interferons and interleukins, preventing viral infection and other external factors affect the tissues. In our analysis we did not observe histological changes such as inflammatory infiltrates or decrease in the normal amount of these cells.

Cardiomyocytes are highly differentiated cells and soon after the first years of life cease to multiply, thus, the growth of the heart is the result of hypertrophy, not of hyperplasia. The apoptosis of cardiomyocytes, for example, as a result of a myocardial infarction, triggers the process of increasing the production of connective tissue, affecting their contractile function as a result of tissue fibrosis, which depending on its extension, may lead to heart failure. Heart failure is a public health problem with high annual rates of morbidity and mortality in both developed and developing countries (SCORSIN and GUARITA-SOUZA, 2001). The extract of $A$. brasiliensis is also indicated as an antioxidant (SOARES, SOUZA, DANIEL et al., 2009), and thus can prevent the risk of fibrosis and heart failure, possibly acting as bioprotector. On the other hand, studies have reported the harmful and toxic activity of the same compound (MUKAI, WATANABE, ANDO et al., 2006).

In this study there were no morphological changes suggesting toxicity and structural changes in the heart. We observed the formation and organization by layers, through staining with $\mathrm{HE}$. In the cardiac structure was possible to visualize the two lower chambers, the right and left ventricles, with partial view of the papillary muscles. It was noted that the left ventricle is thicker than the right. The muscle fibers were presented oriented in the longitudinal and transverse direction relative to the organ. The results showed the interventricular septum formed by several layers and cell nuclei. Using the Picrossirius technique (PS), muscle fibers were stained yellow and the bundle of collagen fibers exposed in red and green. Under polarized light, it was possible to identify the main types of collagen present in the heart: Types I and III.

Possibly there were not morphological changes in the heart as it is not the primary target in cases of toxicity; liver is responsible for metabolizing drugs (MUKAI, WATANABE, ANDO et al., 2006). Another important factor is the lack of research examining morphological changes in the heart and other organs with the use of herbal medicines.

Therefore, in contrast to these various studies indicating deleterious effects on tissues induced by herbal medicine, our study clearly revealed microscopic histological aspects of bundles of muscle fibers and collagen in the heart of Swiss mice, whereas they did not differ structurally from animals treated chronically and not treated with the extract of $A$. brasiliensis.

In our histological observations, the heart showed to be similar to other mammals, indicating a characterization similar to that found by Guimarães (2009) and Crick, Sheppard, Ho et al. (2002), and the arrangement of collagen fibers that form the lining of the heart organ, without changes.

\section{Conclusion}

We conclude that there were no changes of the structural heart of Swiss mice in the chronic use of the extract of A. brasiliensis, suggesting that this extract does not cause morphological changes in cardiac tissue. However, it is highly important to analyze the morphology of other organs as well as the heart itself in different age groups and / or prolonged period of use of the extract. It is also necessary more research employing other specific techniques to elucidate this theme.

\section{References}

BALBINO, EE. and DIAS, MF. Farmacovigilância: um passo em direção ao uso racional de plantas medicinais e fitoterápicos. Revista Brasileira de Farmacognosia, 2010, vol. 20, n. 6, p. 992-1000. http://dx.doi. org/10.1590/S0102-695X2010005000031.

BOLINA, CS., BOLINA-MATOS, RS., ALVES, PHM., CURY, DP., CIENA, AP. and WATANABE, IS. Three-dimensional aspects of the 
structural characteristics and kidney angioarchitecture of adult and aged Wistar rats: a scanning electron microscopy study. Microscopy Research and Technique, 2013, May, vol. 76, n. 5, p. 538-544. http://dx.doi. org/10.1002/jemt.22197. PMid:23450772.

BRAZ, AS., PAULA, AP., DINIZ, MFFM. and ALMEIDA, RN. Uso da terapia não farmacológica, medicina alternativa e complementar na fibromialgia. Revista Brasileira de Reumatologia, 2011, vol. 51, n. 3, p. 275-282. http://dx.doi.org/10.1590/S0482-50042011000300008.

CARRASCHI, L., ZAUPA, C., TSUZUKI, JK., GABRIEL, M., USHIROBIRA, TMA., KANESHIMA, EN., SILVA, JC., AKIMOTO, LS. and MARQUES, LC. Estudo toxicológico pré-clínico do produto fitoterápico Biotoss ${ }^{\circledR}$ em roedores. Revista Brasileira de Ciências Farmacêuticas, 2003, vol. 84, n. 3, p. 91-96.

COLAUTO, NB., DIAS, ES., GIMENES, MA. and EIRA, AF. Genetic characterization of isolates of the basidiomycete Agaricus blazei by RAPD. Brazilian Journal of Microbiology, 2002, vol. 33, n. 2, p. 131-133. http://dx.doi.org/10.1590/S1517-83822002000200006.

CRAGG, GM. and NEWMAN, DJ. Biodiversity: a continuing source of novel drug leads. Pure and Applied Chemistry, 2005., vol. 77, n. 1, p. 7-24. http://dx.doi.org/10.1351/pac200577010007.

CRICK, SJ., SHEPPARD, MN., HO, SY., GEBSTEIN, L. and ANDERSON, RH. Anatomy of the pig heart: comparisons with normal human cardiac structure. Journal of Anatomy, 2002, vol. 193, n. 1.

DURO, CC., CIENA, AP., ALMEIDA, SR., RIGHETTI, MM., GRISOLIA, DF., ISSA, JPM., SILVA, MC. and WATANABE, IS. Qualitative study of young, adult, and aged Wistar rats temporomandibular synovial membrane employing light, scanning, and transmission electron microscopy. Microscopy Research and Technique, 2012, November, vol. 75, n. 11, p. 1522-1527. http://dx.doi.org/10.1002/jemt.22095. PMid:22791633.

GUIMARÃES, JP. Análise Morfológica e Ultra-estrutural do Coração do Lobo-Marinho-do-Sul (Arctocephalusaustralis, Zimmermamm, 1783). São Paulo: Faculdade de Medicina Veterinária e Zootecnia; Universidade de São Paulo, 2009. [Dissertação de Doutorado em Ciências].

HENRIQUES, GS., SIMEONE, MLF. and AMAZONAS, MALA. Avaliação in vivo da qualidade protéica do champignon do Brasil (Agaricus brasiliensis Wasser et al.). Revista de Nutrição, 2008, vol. 21, n. 5 .

JUNQUEIRA, LC., BIGNOLAS, G. and BRENTANI, RR. Picrosirius staining plus polarization microscopy, a specific method for collagen detection in tissue sections. The Histochemical Journal, 1979, July, vol. 11, n. 4, p. 447-455. http://dx.doi.org/10.1007/BF01002772. PMid:91593.

KOMURA, DL., CARBONERO, ER., GRACHER, AHP., BAGGIO, CH., FREITAS, CS., MARCON, R., SANTOS, ARS., GORIN, PAJ. and IACOMINI, M. Structure of Agaricus spp. fucogalactans and their anti-inflammatory and antinociceptive properties. Bioresource Technology, 2010, August, vol. 101, n. 15, p. 6192-6199. http:// dx.doi.org/10.1016/j.biortech.2010.01.142. PMid:20363124.

LINDEQUIST, U., RAUSCH, R., FÜSSEL, A. and HANSSEN, HP. Higher fungi in traditional and modern medicine. Medizinische Monatsschrift fur Pharmazeuten, 2010, February, vol. 33, n. 2, p. 40-48. PMid:20184262.

MELLO, FB., LANGELOH, A. and MELLO, JRB. Estudo de Toxicidade pré-clínica de fitoterápico contendo Pimpinella anisum, Foeniculum foeniculum, Sambucus australise Cassia angustifólia. Latin American Journalof Pharmacy, 2007, vol. 26, n. 2, p. 230-237.

MELlO, JRB., MELLO, FB. and LANGELOH, A. Toxicidade préclínica de fitoterápico com Anemopaegma mirandum, Cola nitida, Passiflora alata, Paullinia cupana, Ptychopetalum olacoidese Tiamina. Latin American Journal of Pharmacy, 2010, vol. 29, n. 1, p. 57-63.

MOURÃO, F., LINDE, GA., MESSA, V., CUNHA JÚNIOR, PL., SILVA, AV., EIRA, AF. and COLAUTO, NB. Antineoplasic activity of Agaricus brasiliensis basidiocarps on different maturation phases. Brazilian Journal of Microbiology, 2009, October, vol. 40, n. 4, p.
901-905. http://dx.doi.org/10.1590/S1517-83822009000400022. PMid:24031439.

MUKAI, H., WATANABE, T., ANDO, M. and KATSUMATA, N. An alternative medicine, Agaricus blazei, may have induced severe hepatic dysfunction in cancer patients. Japanese Journal of Clinical Oncology, 2006, December, vol. 36, n. 12, p. 808-810. http://dx.doi. org/10.1093/jjco/hyll08. PMid:17105737.

NAGATA, J., HIGASHIUESATO, Y., MAEDA, G., CHINEN, I., SAITO, M., IWABUCHI, K. and ONOĒ, K. Effects of watersoluble hemicellulose from soybean hull on serum antibody levels and activation of macrophages in rats. Journal of Agricultural and Food Chemistry, 2001, October, vol. 49, n. 10, p. 4965-4970. http:// dx.doi.org/10.1021/jf0104883. PMid:11600052.

NAKAJIMA, A., ISHIDA, T., KOGA, M., TAKEUCHI, T., MAZDA, O. and TAKEUCHI, M. Effect of hot aqueous extract from Agaricus blazei Murill on antibody producing cells in mice. International Immunopharmacology, 2002, vol. 2, n. 8, p. 1205-1211.

OLIVEIRA, AL., ELER, GJ., BRACHT, A. and PERALTA, RM. Purinergic effects of a Hydroalcoholic Agaricus brasiliensis extract on liver functions. Journal of Agricultural and Food Chemistry, 2010, vol. 58, p. 7202-7210. http://dx.doi.org/10.1021/jfl00804k. PMid:20507067.

PINTO, AVFS., MARTINS, PR., ROMAGNOLI, GG., CAMPANELLI, AP., TEREZAN, AP., RODRIGUES FILHO, E., EIRA, AF. and KANENO, R. Polysaccharide fraction of Agaricus brasiliensis avoids tumor-induced IL-10 production and changes the microenvironment of subcutaneous Ehrlich adenocarcinoma. Cellular Immunology, 2009, vol. 256, n. 1-2, p. 27-38. http://dx.doi.org/10.1016/j. cellimm.2009.01.002. PMid:19243740.

POUCHERET, P., FONS, S. and RAPYOR, S. Biological and farmacological activity of higher fungi: 20-year retrospective analysis. Cryptogamie Mycologie, 2006, vol. 27, n. 4, p. 311-333.

SCORSIN, M. and GUARITA-SOUZA, LC. O transplante celular no tratamento da isuficiência cardíaca. Revista Brasileira de Cirurgia Cardiovascular; Orgao Oficial da Sociedade Brasileira de Cirurgia Cardiovascular, 2001., vol. 16, n. 3, p. 183-186. http://dx.doi. org/10.1590/S0102-76382001000300001.

SINGI, G., DAMASCENO, DD., ANDRÉA, EDD., ALEXANDRE, GMB., SINGI, MB., ALVES, LC. and SIMÕES, T. Efeitos agudos da aplicação endovenosa do cogumelo-do-sol (Agaricus blazei Murill) sobre a pressão arterial média e a freqüência cardíaca de ratos anestesiados. Revista Brasileira de Farmacognosia, 2006, v. 16, n. 4.

SMIDERLE, FR., OLSEN, LM., CARBONERO, ER., MARCON, R., BAGGIO, CH., FREITAS, CS., SANTOS, AR., TORRI, G., GORIN, PA. and IACOMINI, M. A 3-O-methylated mannogalactan from Pleurotus pulmonarius: structure and antinociceptive effect. Phytochemistry, 2008, November, vol. 69, n. 15, p. 2731-2736. http:// dx.doi.org/10.1016/j.phytochem.2008.08.006. PMid:18834999.

SMIDERLE, FR., RUTHES, AC., VAN ARKEL, J., CHANPUT, W., IACOMINI, M., WICHERS, HL. and VAN GRIENSVEN, JL. Polysaccharides from Agaricus bisporus and Agaricus brasiliensis show similarities in their structures and their immunomodulatory effects on human monocytic THP-1 cells. Complementary and Alternative Medicine, 2011, vol. 58, n. 11.

SOARES, AA., SOUZA, CGM., DANIEL, FM., FERRARI, GP., COSTA, SMG. and PERALTA, RM. Antioxidant activity and total phenolic content of Agaricus brasiliensis (Agaricus blazei Murril) in two stages of maturity. Food Chemistry, 2009, vol. 112, n. 4, p. 775-781. http://dx.doi.org/10.1016/j.foodchem.2008.05.117.

Received March 7, 2014 Accepted July 8, 2015 